\title{
Academic patents and entrepreneurial intention. To what extent are other knowledge transfer mechanisms affected in a Mexican university?
}

\begin{abstract}
This research aims to expand the explanations about the debate on academic entrepreneurship and other knowledge transfer mechanisms, to respond to what extent entrepreneurial intention affects the diffusion and dissemination of knowledge in a Mexican university. The lack of indicators of commercial activity, leads us to propose the analysis of a pre-commercial stage of technology that we call entrepreneurial intention. After the literature review, we present a database of academic inventors in patents granted to the university, identifying patenting with an entrepreneurial intention, following Lomas (1993) knowledge transfer taxonomy. Data about publications and received citations by academic inventors is also considered for knowledge diffusion; as well as the supervision of end-of-degree projects in undergraduate and graduate studies; before and after the patent was granted, for knowledge dissemination. Using a binomial model, we estimated two data sets, one for the period 1984-2000 and the second for 2001-2020. Our findings reveal, an average increase of $60 \%$ in the number of patents obtained. We also found that the characteristics of the research group are significant in both models, but in the 2001-2020 period it is more important to integrate foreign inventors than patenting with firms, the dissemination of knowledge is more significant and has greater importance in the model. To respond to what extent entrepreneurial intention affects the diffusion and dissemination of knowledge, greater attention should be paid to the diffusion of knowledge since in both models the variable that represents publications after patenting is not significant. The explanation about the dissemination of knowledge improves substantially from one period to another.
\end{abstract}

Keywords: Academic entrepreneurial intention; Academic patenting; Knowledge transfer; Mexican university

Corresponding author: e-mail: $\mathrm{mgcm} @$ unam.mx

Received October 31, 2019 - Accepted February 12, 2021

This is an Open Access article distributed under the terms of the Creative Commons Attribution-Non-Commercial-No Derivatives License (http://creativecommons.org/licenses/by-nc-nd/4.0/), which permits non-comercial re-use and distribution, provided the original work is properly cited, and is not altered or transformed in any way. 


\section{Introduction}

The role of the entrepreneur has changed with the capitalist system. The success of the entrepreneur is increasingly based on knowledge value. In this context universities have an important role as support agents. This new role of universities is analyzed from different approaches, one of these approaches is the third mission. The third mission describes promotion of economic development, from this approach university requires business management, marketing of the research results, either as patents, R\&D contracts and the creation of spin offs (Guerrero, Cunningham and Urbano 2015; Clark 1998; Etzkowitz and Leydesdorff 2000; Smilor 1990). Perkman et al. (2013), consider that the third mission involves rethinking universities' traditional roles. Other approaches identify these functions with the capitalist system, so they call attention to academic capitalism (Rhoades and Slaughter 2004).

The Bayh-Dole Act allowed American universities and their researchers to market the knowledge created with public resources. This was a fundamental moment for universities, which took an active role in technology transfer, giving rise to the entrepreneurial university (Baldini 2006). University patents have gained attention, both from academics, and from policy makers to promote innovation (Baldini 2006; Verspagen 2006).

In Latin America, since the 1990s the demands and pressures on universities grew, including moving towards an entrepreneurial university model, integrating social, market and political demands. A Latin American version of the entrepreneurial university occurred characterized by: a) the growing internal differentiation, b) postgraduate growth, c) mechanisms to formalize the relationships between the university and the market, d) allocation of incentives and the growth of postgraduate programs in response to the new evaluation mechanisms implemented 
for the expenditure distribution, and e) interaction with the market as a new source of income. In this context, the figure of the academic entrepreneur, describes the research professor who also develops relations and networks with the market, obtaining funds and taking active participation in technology transfer (Acosta 2000; Díaz 2019).

In Mexico, modernization processes in the 1990s were followed by the establishment of public policies to encourage universities to obtain resources from the commercialization of diverse activities. Since then, public resources in universities were allocated through the compliance of governmental constraints, identified in the modernizing programs (Díaz 2019). Mexican universities lately entered the process of incorporating entrepreneurship into their institutional purposes, although entrepreneurship is not part of the country's culture first actions arose in the mid-eighties (Pérez and Varela 2019).

Continuous modifications in public policy and management have limited the creation of indicators of commercial activities in public universities in Mexico. Making it difficult to design adequate models for this context, we use proxy indicators of entrepreneurial intention in a precommercial stage of technology, and a knowledge transfer taxonomy. Lomas (1993) provides a useful taxonomy of knowledge transfer that consists of diffusion, dissemination, and implementation. This research aims to expand the explanations about the debate on academic entrepreneurship and other knowledge transfer mechanisms to respond to what extent entrepreneurial intention affects the diffusion and dissemination of knowledge in a Mexican university.

For Bennett and Gabriel (1999), useful knowledge results when the recipient of the information understands, translates and applies it to specific tasks. Knowledge is perishable, but when 
properly harnessed it can be used in multiple tasks. The activities of appropriation, storage, dissemination and use of knowledge are at the center of knowledge management. The following is the measurement to make the knowledge visible, codify it and process it, to share it with the members of the organization.

As initial assumption, we consider that during the last twenty years the universities have generated responses to balance the demands from government and society. Even though the professors' mission could be oriented towards the diffusion and dissemination of knowledge, there is evidence that identifies their participation in knowledge implementation activities such as patenting. Since knowledge implementation is an active process that involves systematic efforts to encourage adoption of the research findings by identifying and overcoming barriers to their use (Gagnon 2013; Lomas 1993), can be related to an entrepreneurial intention.

After this introduction, the literature review is presented. In the methods section we explain how the database was integrated and using a binomial model, we estimated two data sets, one for the period 1984-2000 and the second for 2001-2020. The comparison of both time series allows to observe changes in protection and diffusion and dissemination of knowledge. Each time series represents the moment before and after the mentioned modernization processes followed by the establishment of public policies in the country. These changes permeated inside the universities modifying their internal regulations.

\section{Theoretical framework}

\subsection{Debate on academic entrepreneurship}

An entrepreneurial university is characterized by: a) the commercialization of knowledge, which would become the basis of economic and social development; b) interaction with firms 
and public sector; c) university independence; d) creation of hybrid administrative structures that incorporate business sector practices, e) reflexive process, to continuously adapt to changes in its relations with the government and business; f) diversity in its sources of financing; $g$ ) autonomy to promote systematic links with the market; h) promotion promotion to adopt a culture oriented towards entrepreneurship (Clark 1998; Etzkowitz and Leydesdorff 2000).

Several studies have documented the process by which the university generates and transfer knowledge and how new innovative firms are created from knowledge (Powell, Kopu and Smith-Doerr 1996, Mowery 2005, Bresnahan, Gambardella and Saxenian 2001). From the perspective of academic capitalism, Slaughter and Rhoades (2004) highlight a link with the market, rational, structured and promoted by universities. Under this proposal, universities produce, and the market commercializes, maintaining the process of wealth creation (Slaughter and Leslie 1997). Academic capitalism affects the dynamics of university through the policy design. Policy makers promote, fund and support commercialization of products and activities generated in the organization, the incorporation of entrepreneurship culture and promote economic relations with industry. Patent licensing and sale, and the creation of spin off companies are some of the most valued activities (Slaughter and Rhoades 2004).

Literature also identifies positions against these new functions in universities, SánchezBarrioluengo $(2014,1760)$ reflects to what extent universities can effectively perform all the functions that society demands. In particular, whether it is possible to incorporate social and business commitment, in response to the social changes that demand that knowledge, created in the university may be productive (Sánchez-Barrioluengo 2014, 1765). Author's studies on innovation policies define for universities a central role as producers of knowledge applied to the creation of firms. However, conclude that there is no compatibility between the missions of 
the university and that universities are not able to meet the expectations of society simultaneously (Sánchez-Barrioluengo 2014, 1770).

Vence $(2010,80)$ states that, in developing countries, firms do not frequently value universities' research results, because their requirements are more specific. According to this author another conflict between industry and universities' rationale, is in the knowledge diffusion and dissemination. Academic sector motivates the diffusion of research findings, even in early stages, and knowledge dissemination through the academic and research training of human resources. In contrasts with industrial protection strategies, an essential condition for private appropriation of knowledge.

Academic entrepreneurship, university-business relationship, academic capitalism and inclusive innovation are fields of research that address this problem based on a specific ideological position. Although we do not ignore this critical part of academic entrepreneurship, we consider important to determine the extent to which Mexican universities have redirected their efforts to academic entrepreneurship and test its effect on other knowledge transfer mechanisms.

\subsection{Academic patents and entrepreneurial intention}

Research on entrepreneurial universities has increased over the years, expanding to interconnected topics, such as entrepreneurship education or academic entrepreneurship (Riviezzo et al. 2019, 232; Fayolle and Redford 2014). Academic entrepreneurship refers to any activity that goes beyond the traditional academic roles of research and teaching and implies innovative activities (Abreu and Grinevich 2013). Five types of academic entrepreneurship can be distinguished: the direct commercial involvement of universities and laboratories, the entry 
into large-scale capital intensive 'big science' by creating and funding large research projects and laboratories, the promotion of supplemental income through consulting, the mobilization of industry support for university science, and patenting and licensing (Dalmarco, Hulsink and Bloisa 2018, 101; Slaughter and Leslie, 1997; Rhoades and Slaughter 2004).

Perkman et al. (2013) define that industry academy collaboration refers mainly to collaborative research, by contract, consulting, informal activities and networking with practitioners. These activities are usually considered informal knowledge transfer mechanisms. On the other hand, in the protection of intellectual property, patenting implies disposition to exploitation, commercialization, licensing, and profiting. A latent hypothesis is that both activities can be part of a continuum where collaboration could be a first stage of formal commercialization. A common feature is that these activities are developed at academics' decision.

Patenting and licensing have not registered significant changes in Mexico. Either nationally or abroad, there is no evidence of the incorporation of Mexican universities in the international knowledge markets (Aboites and Soria 2008). Under this set of approximations, we consider remarkable the effort made by professors and researchers to get involved in the task of patenting abroad. Patenting has demonstrated to foster entrepreneurial activities. Stronger intellectual property rights protection protection increases the returns to innovation via a decrease in the risk of unauthorized expropriation (Gans and Stern 2003), which may act to encourage entrepreneurial entry (Hsu, Roberts and Eesley 1991).

In Mexico, the influence of other regions generated different initiatives to impulse academic entrepreneurship. Two phases can be identified. First, in the early nineties, some initiatives to link academia - High Educational Institutions (HEI) and Public Research Centers (PRC) - 
and firms were characterized by the creation of a few business incubators. Efforts were isolated in academia. An incubator program of Technology Based Enterprises (TBE) was launched in 1992 and interrupted in 1997 due to the lack of skills to support the new firms, as well as rigidity in management and financing mechanisms. Second, starting in 2001, public policies aimed for promoting technological transfer and innovation from a systemic approach. However, in Mexico, science and technology programs did not have an explicit orientation to the development of new TBE (Almeida, Terra and Pérez-Hernández 2011).

The study of entrepreneurial intention is a rapidly evolving field that still requires further research (Fayolle and Liñán, 2014; Liñán and Fayolle, 2015). To advance the understanding on entrepreneurial intention it is necessary to focus on its characteristics (Bell 2019). In the industry the concept based on risk propensity, innovation, and proactiveness has been extensively researched (Covin and Slevin 1989) including other variables such as competitive aggressiveness and autonomy (Lumpkin and Dess 1996). Under Perkman et al. (2013) definitions about the protection of intellectual property, patenting implies the disposition to exploitation, commercialization, licensing, and profiting. In this context, we lack from commercial activity indicators to model academic entrepreneurship, therefore we have identified three categories in which academic researchers add value to pre-commercial technology (Bjørgum and Sørheim 2014).

'Characteristics of research group' is a broad category comprising value-added activities such as collaboration with firms, with other universities and international collaboration which literature review found central (Acosta et al. 2020, 1004; Olmos-Peñuela, Castro-Martínez and D’Este 2014; Hormiga et al. 2017; Barletta et al. 2017), and to some extent the accumulated number of patents granted to the researcher as an indicator of their previous experience 
(Rasmussen and Borch 2010). According to Fini and Toschi (2016) skills and abilities are also predictors of entrepreneurial behaviors because they provide individuals with a better evaluation of the focal behavior, encouraging individual action. For organizations like universities prior knowledge has been conceptualized as determinant of entrepreneurial intention, since it allows recognizing opportunities and triggers the entrepreneurial process (Fini and Toschi 2016; Shane 2000). The awareness of technical and managerial skills develops specific mindsets, prompting the ability to engage in value creation (Baum, Locke and Smith 2001; Fini and Toschi 2016).

Furthermore, 'Knowledge diffusion' category is relevant when evaluating knowledge as valueadded asset to technology and it is especially important in a pre-commercial industry with long and complex technology development processes (Bjørgum \& Sørheim 2014). And finally the category 'Knowledge dissemination' comprises value-added activities such as the production and use of knowledge in human resources training (Hernández and Díaz 2007), this indicator was constructed with the number of degree final projects of pre-grade and postgraduate students supervised by patenting researchers. At the individual level Dohse and Walter (2012), found that role models facilitating the transfer of tacit knowledge and the expectation that strong ties, will provide know-how and know-who positively impact entrepreneurial intentions.

\subsection{Characteristics of research groups}

Unlike most extant analyzes that focus on the university level, we follow the latest strand of literature that consider the factors affecting the production of university outputs at the level of researchers and groups (Acosta et al. 2020, 1004; Olmos-Peñuela, Castro-Martínez and D’Este 2014; Hormiga et al. 2017; Barletta et al. 2017). Individuals' attributes are conditioned by the 
immediate university context. And the establishment of mechanisms to balance academic and commercial interests, and the capabilities to integrate new resources, show a dependence on previous experiences (Rasmussen and Borch 2010).

In addition to patenting, we considered data about the characteristics of the research groups, including international participation or collaboration with firms, with other universities in Mexico or with other inventors in the University and the accumulated number of patents granted to the researcher as an indicator of their previous experience. Academic researchers do not only produce and implement new knowledge, but their performance is also valued in other activities of knowledge diffusion, and knowledge dissemination.

\subsection{Knowledge diffusion}

Diffusion can be defined as those efforts that are passive and largely unplanned, uncontrolled, horizontal or mediated by peers. Publishing in peer-reviewed journals and presenting research results at an academic conference are examples of this type of dissemination (Gagnon 2013; Lomas 1993). In this category the responsibility is on the potential adopter to seek out the information.

D'Este and Perkmann (2011) suggest that: a) commercialization has positive effects on productivity, inventors publish more than academics who do not patent, in collaborative research there is not enough evidence; b) university industry collaboration or marketing activities shifts basic research toward applied research; c) links with industry restrict open communication of research findings with peers (particularly in life sciences) although there is limited evidence; d) there is an increase in the prestige and reputation of academics who carry out these activities and e) there is no evidence of the impact on teaching. 
The knowledge diffusion is a fundamental activity for researchers and universities' mission. We consider important, especially in the case of Mexico due to the statements presented above, to know to what extent these activities can be affected by professors' entrepreneurial intention, at a pre-commercial stage. Data were extracted from the inventors' publications and the citations received before and after patenting.

\subsection{Knowledge dissemination}

Dissemination of knowledge focuses primarily on communicating research results by targeting and tailoring the findings and the message to reach others than academics and researchers. More active dissemination approaches include linking researchers and knowledge users through different mechanisms (Gagnon 2013; Lomas 1993).

In Mexico, incentive and promotion systems consider the training of human resources through teaching and supervision of degree final projects. This activity is mandatory and highly valued. Being a main demand for public universities, human resources training may be a potentially effective mechanism for knowledge dissemination and application. Even though it is not its main purpose, this activity can connect people who might not otherwise have an opportunity to interact, enable dialog, stimulate learning, and capture and diffuse knowledge. This interaction of researchers and professors with students and training researchers, may result in communities of practice, knowledge networks, and soft networks.

An indicator used to identify the production and use of knowledge in human resources training is the degree final projects supervision (Hernández and Díaz 2007), this indicator has also been used to explain the underlying concept of research utilization in the social sector (Huberman 1987). Undergraduate and graduate end-of-degree projects supervised by academic researchers 
were included in database as an indicator for the dissemination of knowledge. This indicator is measured before and after the granted patent.

\section{Methods}

Some authors emphasize the importance of the university's location in places of high economic dynamism in the country, as well as the performance of research activities in scientific fields that are important in the industry (Tijssen 2006). We study the case of Universidad Nacional Autónoma de México (UNAM), due to the availability of information, and its scientific and technological capabilities. According to the data of EXECUM (2020), in Mexico ten HEIs hold the $49.3 \%$ of academic patents, $26 \%$ of this granted to UNAM (Figure 1).

The first article of University's Ley Orgánica establishes purposes of UNAM. These are to provide higher education to train professionals, researchers, university professors and technicians useful to society; organize and perform research, mainly on national conditions and problems, and extend the benefits of culture as widely as possible. There are different orientations in the development of these three substantive activities, Schools and Faculties academic activities are oriented, but not limited, towards teaching and Centers and Institutes that are mainly oriented to research activities. The present analysis focuses on schools and faculties (last are the university schools that offer postgraduate studies). Incentives and promotion mechanisms are the same for professors and researchers, so it is important to investigate to what extent the entrepreneurial intention can affect other substantive missions identified in this research as diffusion and dissemination of knowledge. 


\section{Journal of Evolutionary Studies in Business}

FIGURE 1. Top 10 HEI and PRC in academic patents in Mexico (accumulated to 2018)

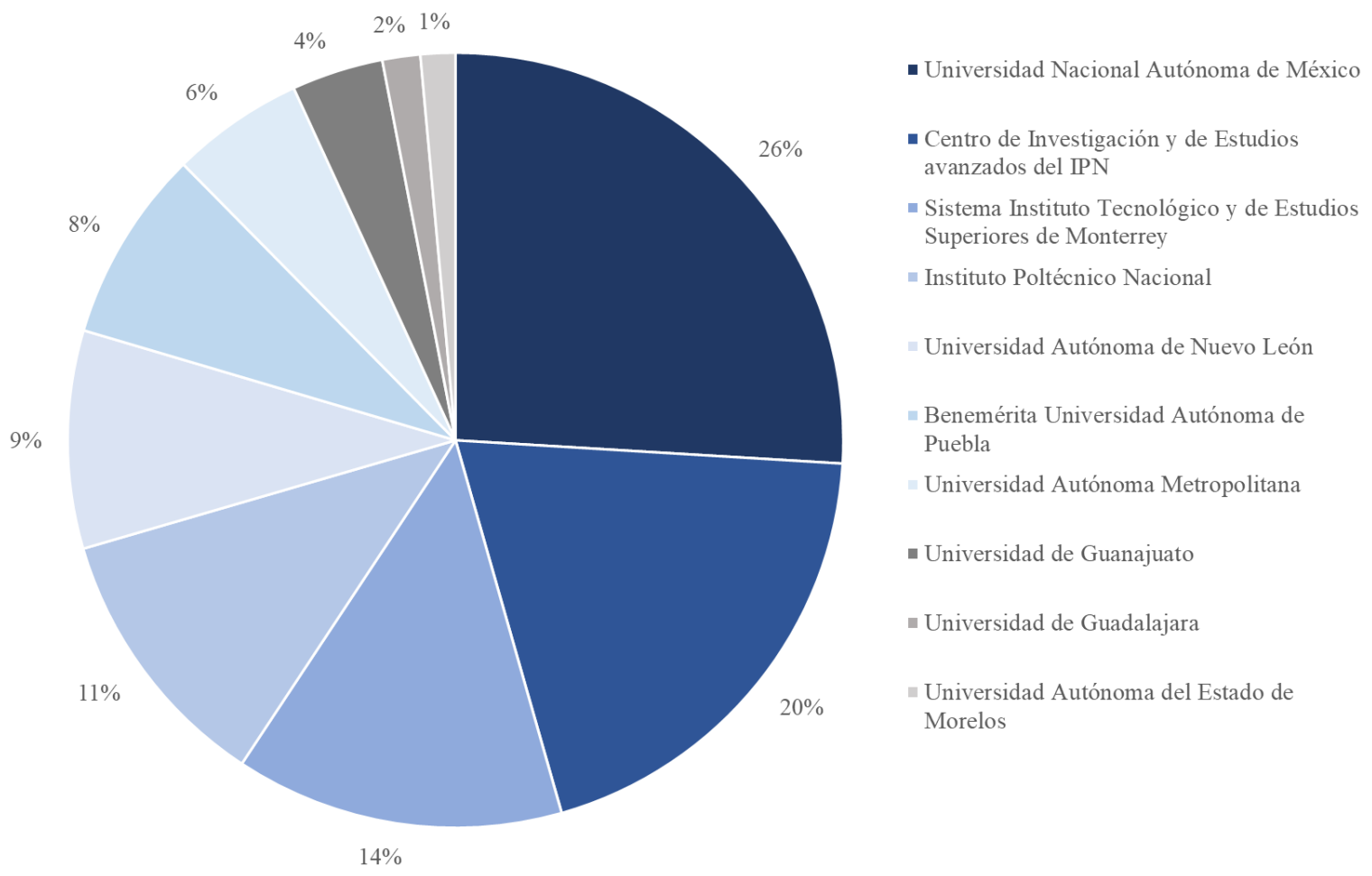

Source: Authors with data of EXECUM (2020).

To build the data base a search for patents granted to UNAM in Mexico and in other countries was conducted. We used Espacenet, — platform of the European Patent Office (EPO) because it detects the greatest number of results as it contains documents in patent offices around the world including the American Patent Office (USPTO). This search was completed with data from SIGA (platform of the Mexican Institute of Industrial Property, IMPI). Our database contains all patents granted from 1984 to 2020.

We completed the database with professor's publications, cites, and supervised end-of-degree projects in undergraduate and graduate studies, before and after the patent granted. Variables were grouped into three categories: a) Characteristics of research groups, b) Knowledge diffusion, and c) Knowledge dissemination mechanisms (Table 1). 
TABLE 1. Variables

\begin{tabular}{|c|c|}
\hline Variable & Description \\
\hline Pat & Value 1 represents granted patents abroad and 0 granted patents in Mexico* \\
\hline PatNum & Number of patents granted to the inventor \\
\hline \multicolumn{2}{|c|}{ Characteristics of research group } \\
\hline IntlColab & $\begin{array}{lllll}\begin{array}{l}\text { International collaboration. Dichotomous } \\
\text { participation of foreign inventors }\end{array} & \text { variable, value } & 1 \text { represents } \\
\end{array}$ \\
\hline InstColab & $\begin{array}{l}\text { Institutional collaboration. Dichotomous variable, value } 1 \text { represents participation } \\
\text { of more than one inventor from UNAM }\end{array}$ \\
\hline ExtAcadColab & $\begin{array}{l}\text { Collaboration with external academic institutions. Dichotomous variable, value } 1 \\
\text { represents co-patenting with inventors from another university }\end{array}$ \\
\hline FirmColab & $\begin{array}{l}\text { Collaboration with firms. Dichotomous variable, value of } 1 \text { indicates co-patenting } \\
\text { with firms }\end{array}$ \\
\hline \multicolumn{2}{|c|}{ Knowledge diffusion } \\
\hline PrevPublic & $\begin{array}{l}\text { Average of publications from the year of the first document in the database and up } \\
\text { to the year of patent application }\end{array}$ \\
\hline PrevCites & $\begin{array}{l}\text { Average citations received from the year of the first document in the database and } \\
\text { up to the year of patent application }\end{array}$ \\
\hline PostPublic & $\begin{array}{l}\text { Average of publications from the following year to the patent application up to } \\
2020\end{array}$ \\
\hline PostCites & $\begin{array}{l}\text { Average citations received from the following year to the patent application up to } \\
2020\end{array}$ \\
\hline \multicolumn{2}{|c|}{ Knowledge dissemination } \\
\hline PrevUndgrad & $\begin{array}{l}\text { Average of under degree projects supervised, from the year of the first entry in the } \\
\text { database until the year of patent application }\end{array}$ \\
\hline PrevMast & $\begin{array}{l}\text { Average of master end-of-degree projects supervised, from the year of the first } \\
\text { entry in the database until the year of patent application }\end{array}$ \\
\hline PrevPhD & $\begin{array}{l}\text { Average of doctoral end-of-degree projects supervised, from the year of the first } \\
\text { entry in the database until the year of patent application }\end{array}$ \\
\hline PostUndgrad & $\begin{array}{l}\text { Average of under degree projects supervised, from the following year to the patent } \\
\text { application up to } 2020\end{array}$ \\
\hline PostMast & $\begin{array}{l}\text { Average of master end-of-degree projects supervised, from the following year to } \\
\text { the patent application up to } 2020\end{array}$ \\
\hline PostPhD & $\begin{array}{l}\text { Average of doctoral end-of-degree projects supervised, from the following year to } \\
\text { the patent application up to } 2020\end{array}$ \\
\hline
\end{tabular}

Sources: Espacenet patent database, SIGA patent register, Scopus and TesiUNAM.

* Applicants patent first at the IMPI Mexican patent office and then at other countries.

The empirical model specification is like e.g., Lach and Shankerman 2008; Caldera and

Debande 2010 and Calderón-Martínez and García-Quevedo, 2013. The following equation was estimated: 
Pat $=\beta_{0}+\beta_{1}$ RCHARACT $+\beta_{2}$ KDIFF $+\beta_{3}$ KDISSEM $+a_{t}+\varepsilon_{i t}$

Where Pat are patents granted where the inventors are professors from schools or faculties at UNAM. Explanatory variables are RCHARACT an indicator that explains research groups characteristics, KDIFF is an indicator linked to the diffusion of knowledge through scientific articles and citations and KDISSEM controls the dissemination of knowledge measured by the supervision of undergraduate and graduate end-of-degree projects before and after patenting. The estimation also includes number of patents granted to the inventor (Patnum) as a weighting variable.

The following aspects were considered for the model estimation (1). First, patents are counting data, so Poisson or negative binomial models, which consider endogeneity, are preferable to linear regression models estimated by ordinary least squares (Cameron and Trivedi, 1998). However, Poisson models are very restrictive when assuming equality between mean and variance. Consequently, negative binomial models are an appropriate alternative to Poisson models and allow the existence of over dispersion. As in the aforementioned procedure, a relevant problem is the possible endogeneity mainly due to the existence of omitted variables such as, for example, scientific specialization or experience in commercial technology transfer activities.

\section{Results and discussions}

As our hypothesis consider that during the last twenty years the UNAM has generated responses to balance the demands from the government and society, we analyzed two different sets of time 1984-2000 and 2001-2020. The comparison of both time series allows to observe changes in protection and diffusion and dissemination of knowledge. Each time series represents the 
moment before and after the mentioned modernization processes followed by the establishment of public policies in the country. These changes, of course, also permeated inside the universities, modifying their internal regulations.

Among professors who have patented, the average number of patents granted increased from 2.33 to 3.66 during the analyzed periods of time (Figure 2).

FigURE 2. Average of patents granted to professors at schools and faculties in UNAM
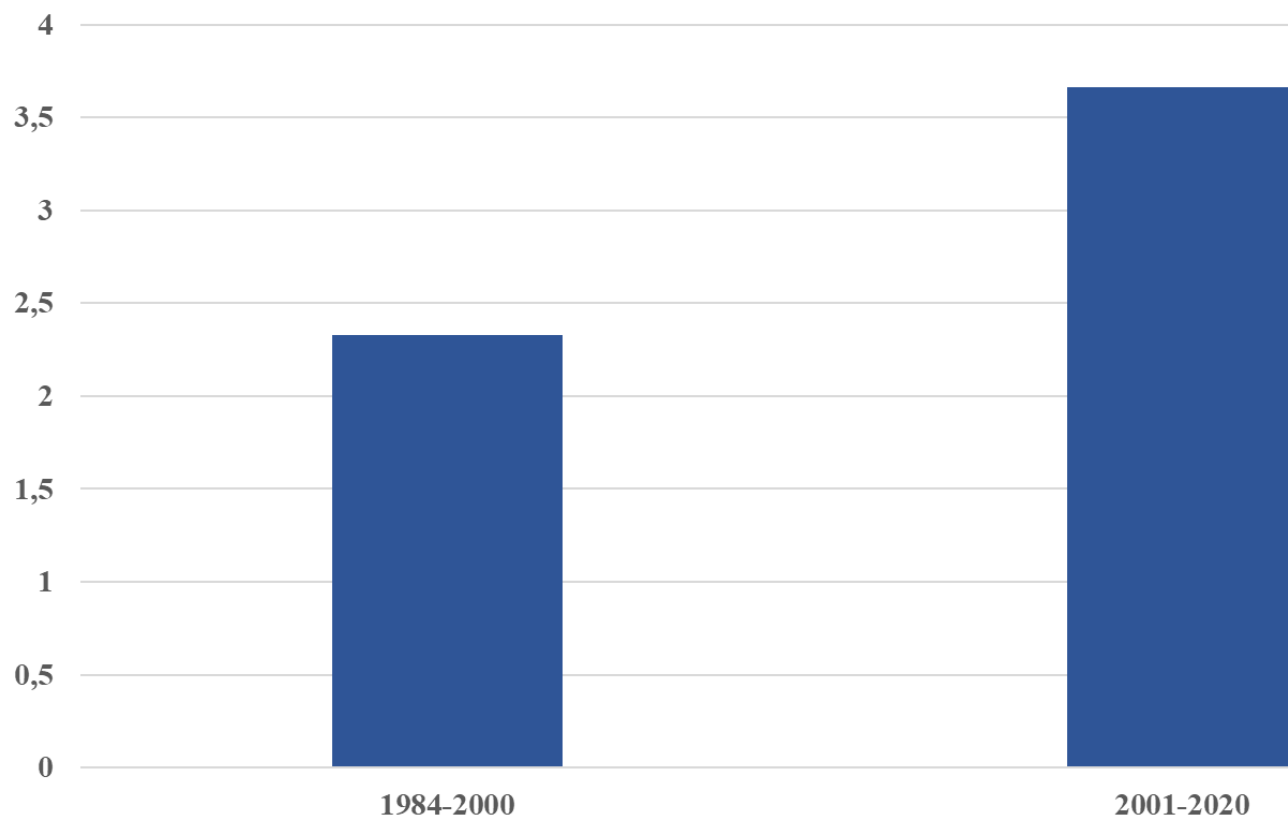

2001-2020

Source: Authors.

The variable that measures the number of patents granted to the inventor is included, since it is highly significant and improves the estimation. Results in table 2, show during the first analyzed period 1984-2000, that the characteristics of the research group are significant for patenting abroad. Institutional Collaboration, External Academic Collaboration and Firm Collaboration mainly, this variable shows that academic inventors in schools and faculties that do not collaborate with firms are nine times less likely to patent abroad. However, during the following period 2001-2020, this variable is not significant for the model. This may be relevant in the 
sense that professors could have generated the skills to patent abroad independently of a relationship with a firm.

TABLE 2. Model estimations

\begin{tabular}{|l|c|c|c|c|}
\hline Variable & \multicolumn{2}{|c|}{$\mathbf{1 9 8 4 - 2 0 0 0}^{*}$} & \multicolumn{2}{c|}{ 2001-2020*** } \\
\hline & $\mathbf{E x p}(\mathbf{B})$ & Sig. & $\operatorname{Exp}(\mathbf{B})$ & Sig. \\
\hline IntlColab & 2.053 & .270 & 3.949 & .001 \\
\hline InstColab & .291 & .001 & .441 & .001 \\
\hline ExtAcadColab & 6.044 & .047 & .278 & .024 \\
\hline FirmColab & 10.129 & .019 & 1.026 & .928 \\
\hline PrevPublic & .156 & .009 & .489 & .083 \\
\hline PrevCites & .920 & .366 & 1.008 & .682 \\
\hline PostPublic & 1.755 & .148 & .996 & .974 \\
\hline PostCites & 1.026 & .047 & 1.010 & .051 \\
\hline PrevUndgrad & .114 & .035 & .824 & .376 \\
\hline PrevMast & 5.699 & .196 & .213 & 0.78 \\
\hline PrevPhD & .911 & .977 & 6.668 & .003 \\
\hline PostUndgrad & .630 & .609 & .639 & .015 \\
\hline PostMast & 10.337 & .138 & 2.433 & .010 \\
\hline PostPhD & .002 & .047 & .058 & .058 \\
\hline
\end{tabular}

Note: Model fitness measures * Chi squared $58.67 \% * *$ Chi squared $63.59 \%$.

We consider that this finding is an important reflection for entrepreneurial intention, because in this model the variable that measures collaboration with foreign inventors has become significant, showing that professors that do not collaborate with foreign inventors are almost three times less likely to patent abroad. This may represent the preference for the establishment of agreements with persons than the formalization of relationships with firms. Our data does not allow to know if foreign inventors belong to a specific organization. But this could be a result of the continuous changes in regulation over the last thirty years in Mexico. This is an opportunity research area for universities and for decision makers at the governmental level.

Regarding the variables that represent the diffusion of knowledge, similar results are observed in both periods of time. Publications before patenting are significant, as well as citations received after patenting. This must be considered since it could provide information about the 
debate between entrepreneurial activity and the diffusion of knowledge. Variables that measure professors' publications after the patent granted are less significant in the period 2001-2020. We observe a greater significance of variables related to knowledge dissemination in the period 2001-2020. Supervision of doctoral end-of-degree projects before patenting, and the supervision of end-of-degree projects in both undergraduate and graduate after patenting are significant.

\section{Conclusions}

As in previous research, we report a growing demand for universities, not only in Mexico, to participate in knowledge transfer activities. Regulatory changes have been continuous in the last thirty years in Mexico. Some of these changes were intended to promote greater participation between universities and firms for knowledge commercialization, to impulse entrepreneurship in universities. Our study shows greater significance in the collaboration between persons, as well as between researchers from the university and with other academic institutions in the country.

In a pre-commercial stage of technology entrepreneurial intention is observed in the active process that involves systematic efforts to encourage adoption of the research findings by identifying and overcoming barriers to their use, as seen in the group of variables that represents the characteristics of the research group. The importance of each variable changes in the model in each time frame.

Research results lead to open discussion about the debate on academic entrepreneurship and other knowledge transfer mechanisms to respond to what extent entrepreneurial intention affects the diffusion and dissemination of knowledge in a Mexican university. This work has 
focused on the analysis of academic patents that, although it is still a rare way of interaction, have experienced a notable increase in the last two decades.

Variables that measure professors' publications after patenting are less significant in the period 2001-2020. This must be considered since it could provide information about the debate between entrepreneurial activity and the diffusion of knowledge. We observe a greater significance of variables related to knowledge dissemination in the period 2001-2020. Supervision of doctoral end-of-degree projects before patenting, and the supervision of end-ofdegree degree projects in both undergraduate and graduate degrees after patenting are significant for the model.

Results are relevant since they report advances in the relationship between professors' entrepreneurial intention and the dissemination of knowledge. According to the results obtained, we consider necessary to obtain stronger evidence in order to generalize research findings, so it is necessary to include UNAM's Institutes and Research Centers granted patents. As seen on Figure 1, this institution can be highly representative of the patents granted to universities in Mexico.

As an initial assumption, we consider that during the last twenty years universities have generated responses to balance the demands from the government and society. In this study we consider patents in Schools and Faculties, because professors' mission could be oriented towards the diffusion and dissemination of knowledge. Lack from commercial activity indicators to model academic entrepreneurship led us to consider a pre-commercial patent stage. Under definitions about the protection of intellectual property, patenting implies the disposition to exploitation, commercialization, licensing, and profiting. Literature review and 
characteristics of research groups show evidence that identifies professors' participation in knowledge implementation activities such as patenting, motivated by an entrepreneurial intention. Since knowledge implementation is an active process that involves systematic efforts to encourage adoption of the research findings by identifying and overcoming barriers to their use.

To respond to what extent entrepreneurial intention affects the diffusion and dissemination of knowledge, greater attention should be paid to the diffusion of knowledge since in both models the variable that represents publications after patenting is not significant. The explanation about the dissemination of knowledge improves substantially from one period to another. Probably because it is a closer stage to knowledge implementation or because the supervision of final degree projects and the training of human resources are highly valued in incentive and promotion systems. We consider that significance of supervised end-of-degree graduate projects may also be explained by the relationship between the orientation towards applied research. While diffusion is usually considered as basic science. Our estimation can be improved by including data from Centers and Institutes that, due to their research orientation, can expand the explanation of the debate between the different missions of the public university in Mexico. 


\section{References}

Aboites, Jaime and Manuel Soria. 2008. Economía del Conocimiento y Propiedad Intelectual. Lecciones para la economía mexicana. Mexico City: UAM Xochimilco y Siglo XXI Editores.

Abreu, María and Vadim Grinevich. 2013. "The nature of academic entrepreneurship in the UK: Widening the focus on entrepreneurial activities." Research Policy 42: 408-22. doi: 10.1016/j.respol.2012.10.005.

Acosta, Adrián. 2000. "Bajo el cielo ¿protector? De la globalización. Poder y políticas en la educación superior en América Latina.” Perfiles Latinoamericanos 9: 69-93.

Acosta, Manuel, Daniel Coronado, Ma. Dolores León and Pedro J. Moreno. 2020. "The Production of Academic Technological Knowledge: An Exploration at the Research Group Level." Journal of the Knowledge Economy 11: 1003-1025. doi: 10.1007/s13132-019-0586-9.

Almeida, Mariza, Branca Terra and Pilar Perez-Hernández. 2011. "The incubator movement A comparative analysis of Brazil and Mexico." In Theory and practice of the triple helix system in developing countries. Issues and changes, coordinated by Mohamed Saad and Girma Zawdie, 176-189. New York: Routledge studies in innovation, organization, and technology.

Baldini, Nicola. 2006. "University patenting and licensing activity: a review of the literature." Research Evaluation 15: 197-207. doi: 10.3152/147154406781775878.

Barletta, Florencia, Gabriel Yoguel, Mariano Pereira and Sergio Rodríguez. 2017. "Exploring scientific productivity and transfer activities: evidence from Argentinean ICT research groups." Research Policy 46: 1361-69. doi: 10.1016/j.respol.2017.05.007.

Baum, Robert, Edwin Locke and Ken Smith. 2001. "A multidimensional model of venture growth." Academy of Management Journal 44: 292-303.

Bell, Robin. 2019. "Predicting entrepreneurial intention across the university." Education + Training 61: 815-31. doi: 10.1108/ET-05-2018-0117.

Bennett, Roger and Helen Gabriel. 1999. "Organisational factors and knowledge management within large marketing departments: an empirical study.” Journal of Knowledge Management 3: 212-25. doi: doi.org/10.1108/13673279910288707.

Bjørgum, Øyvind and Roger Sørheim. 2015. "The funding of new technology firms in a pre-commercial industry - the role of smart capital." Technology Analysis \& Strategic Management 27: 249-66. doi: doi.org/10.1080/09537325.2014.971002.

Bresnahan, Timothy, Alfonso Gambardella and Annalee Saxenian. 2001 “Old Economy' Inputs for 'New Economy' Outcomes: Cluster Formation in the New Silicon Valleys." Industrial and Corporate Change 10: 835-60. doi: doi.org/10.1093/icc/10.4.835. 
Caldera, Aida and Oliver Debande. 2010. "Performance of Spanish universities in technology transfer: An empirical analysis." Research Policy 39: 1160-73. doi: doi.org/10.1016/j.respol.2010.05.016. Calderón-Martínez, Guadalupe and José García-Quevedo. 2013. "Transferencia de conocimiento y patentes universitarias en México." Academia, Revista Latinoamericana de Administración 26: 33-60. doi: 10.1108/ARLA-05-2013-0039.

Cameron, Colin and Trivedi Pravin. 1998. Regression analysis of count data. New York: Cambridge University Press.

Clark, Burton. 1998. Creating Entrepreneurial Universities: Organizational Pathways of Transformatione. New York: International Association of Universities and Elsevier Science.

Covin, Jeffrey and Dennis Slevin. 1989. "Strategic management of small firms in hostile and benign environments." Strategic Management Journal 10: 75-87. doi: doi.org/10.1002/smj.4250100107.

D'Este, Pablo and Markus Perkmann. 2011. "Why do academics engage with industry? The entrepreneurial university and individual motivations." The Journal of Technology Transfer 36: 316-39. doi: 10.1007/s10961-010-9153-Z.

Dalmarco, Gustavo, Willem Hulsink and Guilherme Bloisa. 2018. "Creating entrepreneurial universities in an emerging economy: Evidence from Brazil." Technological Forecasting and Social Change 135: 99-111. doi: 10.1016/j.techfore.2018.04.015.

Díaz, Claudia. 2019. "Emprendurismo académico: los inventores de la UAM.” In Aproximaciones a la universidad emprendedora en México, coordinated by Guadalupe Calderón, Claudia Díaz, Marco Jaso y José Luis Sampedro, 45-86. Mexico City: Universidad Autónoma Metropolitana.

Dohse, Dirk and Sacha Walter. 2012. "Knowledge context and entrepreneurial intentions among students." Small Business Economics 39(4): 877-95. doi: 10.1007/s11187-011-9324-9.

Etzkowitz, Henry and Loet Leydesdorff. 2000. "The Dynamics of Innovation: From National Systems and 'Mode 2' to a Triple Helix of University-Industry-Government Relations." Research Policy 29(2): 109-23. doi: . 10.1016/S0048-7333(99)00055-4.

Execum. 2020. "Estudio Comparativo de Universidades Mexicanas. Explorador de Datos Universidad Nacional Autónoma de México. Dirección General de Evaluación Institucional”. Accessed August $4^{\text {th }}, 2020$ : http://www.execum.unam.mx/.

Fayolle, Alain and Francisco Liñán. 2014. "The future of research on entrepreneurial intentions." Journal of Business Research 67(5): 663-66.

Fayolle, Alain and Dana T. Redford. 2014. Handbook on the Entrepreneurial University. Cheltenham: Edward Elgar.

Fini, Ricardo and Laura Toschi. 2016. "Academic logic and corporate entrepreneurial intentions: A study of the interaction between cognitive and institutional factors in new firms." International 
Small Business Journal: Researching Entrepreneurship 34(5): 637-59. doi: doi.org/10.1177/0266242615575760.

Gagnon, Michelle. 2009. "Moving knowledge to action through dissemination and exchange." Journal of Clinical Epidemiology 64: 25-31. doi: 10.1016/j.jclinepi.2009.08.013. Epub 2009 Dec 11.

Gans, Joshua and Scott Stern. 2003. "The product market and the market for "ideas": commercialization strategies for technology entrepreneurs." Research Policy 32: 333-50.

Guerrero, Maribel, James Cunningham and David Urbano. 2015. "Economic impact of entrepreneurial universities' activities: An exploratory study of the United Kingdom.” Research Policy 44: 74864. doi: 10.1016/j.respol.2014.10.008.

Hernández, Sergio y Eliseo Díaz. 2007. "La producción y el uso del conocimiento en México y su impacto en la innovación: análisis regional de las patentes solicitadas." Análisis Económico, 22: 185-17.

Hormiga, Esther, Petra de Saá-Pérez, Nieves Díaz-Díaz, José Luis Ballesteros-Rodríguez and Inmaculada Aguiar-Diaz. 2017. "The influence of entrepreneurial orientation on the performance of academic research groups: the mediating role of knowledge sharing." The Journal of Technology Transfer 42: 10-32.

Hsu, David, Edward Roberts and Charles Eesley. 2007. "Entrepreneurs from technology-based universities: Evidence from MIT." Research Policy 36(5): 768-88. doi: doi.org/10.1016/j.respol.2007.03.001.

Huberman, Michael. 1987. “Steps Toward an Integrated Model of Research Utilization”. Knowledge 8, (June 1987): 586-11. doi: 10.1177/0164025987008004002.

Lach, Saul and Marc Shankerman. 2008. "Incentives and invention in universities." Rand Journal of Economics 39: 403-33. doi: doi.org/10.1111/j.0741-6261.2008.00020.x.

Liñán, Francisco and Alain Fayolle. 2015. "A systematic literature review on entrepreneurial intentions: Citation, thematic analyses, and research agenda." International Entrepreneurship and Management Journal 11(4): 907-33. doi: 10.1007/s11365-015-0356-5.

Lomas, Jonathan. 1993. "Diffusion, dissemination, and implementation: who should do what?" Annals of the New York Academy of Sciences 703: 226-237. doi: doi.org/10.1111/j.17496632.1993.tb26351.x.

Lumpkin, Thomas and Gregory Dess. 1996. "Clarifying the Entrepreneurial Orientation Construct and Linking It to Performance." The Academy of Management Review 21: 135-72. doi: 10.5465/amr.1996.9602161568.

Mowery, David. 2005. "The Bayh Dole Act and High Technology Entrepreneuship in US Universities: chicken, egg or something else.” In University Entrepreneurship and Technology Transfer, edited 
by Gary D. Libecap, 39-68. Amsterdam: Elsevier.

Olmos-Peñuela, Julia, Elena Castro-Martínez and Pablo D’Este. 2014. “Knowledge transfer activities in social sciences and humanities: explaining the interactions of research groups with nonacademic agents.” Research Policy 43: 696-706. doi: 10.1016/j.respol.2013.12.004.

Pérez, Pilar and Martha Varela. 2019. "Cultura emprendedora universitaria: el caso del Instituto Politécnico Nacional". In Aproximaciones a la universidad emprendedora en México, coordinated by Guadalupe Calderón, Claudia Díaz, Marco Jaso y José Luis Sampedro, 155-192. Mexico City: Universidad Autónoma Metropolitana.

Perkmann, Markus, Valentina Tartari, Maureen McKelvey, Erkko Autio, Anders Broström, Pablo D’Este, Riccardo Fini, Aldo Geuna, Rosa Grimaldi, Alan Hughes, Stefan Krabel, Michael Kitson, Patrick Llerena, Francisco Lissoni, Ammon Salter, and Maurizio Sobrero. 2013. "Academic engagement and commercialization: A review of the literature on university-industry relations." Research Policy 42: 423-42.

Powell, Walter, Kenneth Kopu and Laurel Smith-Doerr. 1996 "Inter-organizational Collaboration and the Locus of Innovation: Networks of Learning in Biotechnology." Administrative Science Quarterly 41(1): 116-45.

Rasmussen, Elinar and Odd Borch. 2010. "University capabilities in facilitating entrepreneurship: A longitudinal study of spin-off ventures at mid-range universities." Research Policy 39(5): 602612. doi: 10.1016/j.respol.2010.02.002.

Rhoades, Gary and Sheila Slaughter. 2004. "Academic Capitalism in the New Economy: Challenges and Choices." American Academic 1: 37-59.

Riviezzo, Angel, Susana C. Santos, Francisco Liñán, Maria Rosaria Napolitano, Floriana Fusco. 2019. "European universities seeking entrepreneurial paths: the moderating effect of contextual variables on the entrepreneurial orientation-performance relationship." Technological Forecasting \& Social Change 141: 232-48. doi: 10.1016/j.techfore.2018.10.011.

Salughter, Sheila and Larry Leslie. 1997. Academic Capitalism. Politics, Policies, and the Entrepreneurial University. Baltimore: Johns Hopkins University Press.

Sánchez-Barrioluengo, Mabel. 2014 “Articulating the 'three-missions' in Spanish universities." Research Policy 43: 1760-1773. doi: 10.1016/j.respol.2014.06.001.

Shane, Scott. 2000. "Prior knowledge and the discovery of entrepreneurial opportunities." Organization Science 11: 367-472. doi: 10.1287/orsc.11.4.448.14602.

Slaughter, Sheila and Gary Rhoades. 2004. Academic Capitalism and the New Economy: Markets, State, and Higher Education. Baltimore: Johns Hopkins University Press.

Smilor, Raymond. 1987. The Art and Science of Entrepreneurship. Cambridge: Ballinger. 


\section{Journal of Evolutionary Studies in Business}

Tijssen, Robert. 2016. "Universities and industrially relevant science: Towards measurement models and indicators of entrepreneurial orientation." Research Policy 35: 1569-85. doi: 10.1016/j.respol.2006.09.025.

Vence, Xavier. 2010. "La investigación universitaria frente al corsé de las patentes y la mercantilización del conocimiento y la empresa privada." In Construir el futuro de la universidad pública, coordinated by Albert Corominas y Vera Sacristan, 77-100. Barcelona: Icaria Editoria.

Verspagen, Bart. 2006. "University research, intellectual property rights and European innovation systems.” Journal of Economic Surveys 20(4): 607-632. 